\title{
In silico Study on the Promising Active Components of Terpenoid and Fucoidon from Sargassum sp. in Inhibiting CGRP and TNF-a
}

\author{
Olivia Mahardani Adam ${ }^{1, *}$, Jusak Nugraha ${ }^{2}$, Mohammad Hasan Machfoed ${ }^{3}$, Agus Turchan ${ }^{4}$
}

\section{Olivia Mahardani Adam ${ }^{1, *}$, Jusak Nugraha ${ }^{2}$, Mohammad Hasan Machfoed $^{3}$, Agus Turchan ${ }^{4}$}

'Department of Neurology, Faculty of Medicine, Universitas Hang Tuah, Surabaya, INDONESIA.

${ }^{2}$ Department of Clinical Pathology, Faculty of Medicine, Universitas Airlangga, Surabaya, INDONESIA.

${ }^{3}$ Department of Neurology, Faculty of Medicine, Universitas Airlangga, Surabaya INDONESIA.

${ }^{4}$ Department of Neurosurgery, Faculty of Medicine, Universitas Airlangga, Surabaya INDONESIA.

\section{Correspondence}

Olivia Mahardani Adam

Department of Neurology, Faculty of Medicine, Universitas Hang Tuah, Surabaya, INDONESIA

Phone no: $+6231-8438750$

E-mail: olivia.mahardani@hangtuah.ac.id History

- Submission Date: 01-10-2021;

- Review completed: 09-11-2021.

- Accepted Date: 09-11-2021.

DOI : 10.5530/pj.2021.13.221

Article Available online http://www.phcogj.com/v13/i6

\section{Copyright}

(C) 2021 Phcogj.Com. This is an openaccess article distributed under the terms of the Creative Commons Attribution 4.0 International license.

\begin{abstract}
Introduction: The new discovery of the active substance in Sargassum sp marks the new era for drug industry as it is very effective as the new migraine medication compared to analgesics which have already been popular previously in treating migraine. By using the in silico methods, this study intended to identify the preventive effect of the active substance in Sargassum $s p$ within the stage of pain and inflammation development in migraine. In migraine pathophysiology, the clinical findings would build and verify the role of CGRP and TNF-a. Methods: This research applied a one-shot experimental study and by employing the potential test through PubChem (https://pubchem.ncbi.nlm.nih.gov/), the result of this study proved that tannins, terpenoids and fucoidone were contained in the active substance of Sargassum sp leading to the possession of potential as the drug to treat migraine. Results: Terpenoids and tannin binding affinity value is higher than other substances. Terpenoids and fucoidon had similar amino acid residues with controls Seaweed metabolites have great potential as inhibitors of CGRP and TNF- $\alpha$ because the binding affinity score is close to control. Conclusion: The active substance in Sargassum sp has an inhibitory effect on the occurrence of CGRP and TNF- $\alpha$ in migraine based on in silico studies.

Key words: CGRP, Fucoidone, In silico, Sargassum sp., Terpenoid, TNF- $\alpha$
\end{abstract}

\section{INTRODUCTION}

Generally, seaweed carries three phyla consisting of Chlorophyceae (green algae), Phaeophyceae (brown algae), and Rhodophyceae (red algae). In every phylum, it comprises with thousands of various species. In Asian countries, seaweed has been familiarly utilized as both foods and traditional remedy ages ago by many people. Known as the source of functional metabolites, the people's attention has grown greatly toward $\mathrm{it}^{1,2}$. Some of its functional metabolites possessed by seaweed are its potentials as antibacterial, antiviral, anticancer, anti-hypersensitive, anti-diabetic and antiinflammatory. Thus, the 2020 database from Food and Agriculture Organization (FAO) recorded the increase production of seaweed has been tripled from 10.6 million tons in 2000 reaching to 32.4 million tons in 2018 .

Florotanin, fucoxanthin, fucoidan, alginate, fukosterol, merodit- erpenoids and phenolic acids are the dominant types of bioactive compounds in Sargassum sp. The biological activity of the bioactive compound Sargassum sp. namely antioxidant, anticancer, antitumor, antiallergic, anti-inflammatory, antihypertensive, antiobesity, antidiabetic, antimicrobial, anti-browning, neuroprotective and hypocholesterolemic. ${ }^{1,2}$ Terpenoids can influence various mechanisms of inflammation arising in response to various etiological factors because comprehensive studies of terpenoid mechanisms have shown therapeutic effects on inflammation. ${ }^{3}$

In many previous studies, the role of calcitonin gene-related peptide (CGRP) in migraine pathophysiology has been identified and confirmed by clinical findings. Capi's study revealed that trigeminal ganglia neurons secrete CGRP then multiply its transcription under the conditions of mimicking the neurogenic inflammation and pharmacotherapy in migraine by impeding CGRP transcription and lessening the CGRP release as well as tumor necrosis factor $\alpha$ (TNF- $\alpha$ ) which is an endogenous inflammatory mediator implicated in migraine. ${ }^{4}$

In silico method can be effectively employed in finding the interplay of active substances with Sargassum sp. up to the molecular level. In silico study is highly considered as the primary step in discovering the candidate of treatments or remedy prior to both in vitro or in vivo investigations. ${ }^{5,6}$ This investigation intended to examine and analyze the preventive effects in the active substances of Surgassum $s p$ in contrast to the development of CGRP and TNF- $\alpha$ in migraine.

\section{MATERIALS AND METHODS}

This investigation employed a one-shot experimental study type applying an in silico method which was conducted at the INBIO Biomolecular \& Bioinformatics Laboratory located in Lowokwaru, Malang, East Java, Indonesia.

\section{Protein structure and ligand}

The database of PubChem (https://pubchem.ncbi. nlm.nih.gov/) was utilized as the source in which the active substances from Sargassum $s p$ was obtained from as shown in Table 1. The The three-dimension structure of CGRP and TNF- $\alpha$ a was generated from the database of INBIO Laboratory or from Research Collaboratory for Structural Bioinformatics Protein Data Bank (RCSB PDB) (https://www.rcsb.org/). ${ }^{\text {? }}$

\section{Molecular docking}

Autodock Vina on the PyRx 9.5 program was utilized for molecular docking process. Table 2 presents the targets of molecular docking process in the form of proteins. 
Table 1: Ligand used from Sargassum sp.

$\begin{array}{cc}\text { PUBCHEM } 16133892 & \text { Tannin } \\ \text { PUBCHEM 92023653 } & \text { Fucoidan } \\ \text { PUBCHEM 451674 } & \text { Triterpenoid }\end{array}$

Table 2: Protein Target.

\begin{tabular}{lll}
\hline ID & & Control Inhibitor \\
PDB 3N7I & CGRP & Olcegepant \\
& Receptor & 6,7-DIMETHYL-3-[(METHYL\{2- \\
& & [METHYL(\{1-[3-(TRIFLUOROMETHYL) \\
PDB 2AZ5 & TNF- $\alpha$ & PHENYL]-1H-INDOL-3-YL $\}$ METHYL) \\
& & AMINO]ETHYL $\}$ AMINO)METHYL]-4H- \\
& & CHROMEN-4-ONE
\end{tabular}

From the molecular docking process, it was derived the forecast of the interaction potency between receptor and ligand in regard to their binding affinity. More negative scores indicated stronger relation. The indication that the antagonist activity happened from the examined substance toward the target protein when the tested substance displayed the score which was close to the control one. Olcegepant and 6,7-DIMETHYL-3-[(METHYL\{2-[METHYL(\{1-[3(TRIFLUOROMETHYL)PHENYL]-1H-INDOL-3-YL\}METHYL) AMINO]ETHYL $\quad$ AMINO)METHYL]- 4H-CHROMEN-4-ONE became the protein target of this docking process. The visualization of molecular docking result was derived by using PyMol 2.3.1. LigPlot 2.1. was applied to generate the interaction of amino acid. The bond between the receptor and the control inhibitor was imitated using a grid box as a special docking process performed in this investigation.

\section{RESULTS}

\section{Analysis molecular docking}

A specific docking process performed in this investigation with the imitation of the bond between the receptor and the inhibitor control drug using a grid box. The prediction of the interaction's potency between the receptor and the ligand in regard to the binding affinity score was estimated using the docking process. A stronger interplay existed between the receptor and the ligand was displayed by more negative value. It also could indicate that an activity as the inhibitor of target protein by metabolite which was close to the capabilities of drug inhibitor when the examined metabolites possessed the score near the control one.

Sargassum sp comprised with active substances which included tannin, triterpenoid and fucoidan. The binding affinity for each substance with CGRP and TNF- $\alpha$ was indicated using the molecular docking. The indication of stronger relation was revealed by the more negative score of binding affinity. The crystal structure complex of CGRP with olcegepant as the control inhibitor, also with TNF- $\alpha$ with 6,7-DIMETHYL-3[(METHYL\{2-[METHYL(\{1-[3-(TRIFLUOROMETHYL) PHENYL]1H-INDOL-3YL\}METHYL)AMINO]ETHYL\} AMINO)METHYL]$4 \mathrm{H}$-CHROMEN-4-ONE as the control inhibitor was the target of this molecular docking. Figure 1 and 2 display the visualization of molecular docking's result by PyMol 2.3.1. Table 3 presents that the most negative score was revealed in tannin with the strongest affinity compared to CGRP, followed by triterpenoid, control and fucoidan. Meanwhile, Triterpenoid displayed the strongest affinity with the most negative score compared to TNF- $\alpha$, followed by control, and fucoidan as shown in Table 4. Based on the docking results, seaweed metabolites have great potential as inhibitors of CGRP and TNF- $\alpha$ because the binding affinity score is close to control. CGRP and TNF- $\alpha$ increased in migraine conditions, it is hoped that the administration of Sargassum $s p$ can help normalize the protein levels.
Four hydrophobic bonds and one hydrogen bonds in amino acid residue were revealed in triterpenoid which was similar to the control as presented in Table 5. Meanwhile, fucoidan displayed three hydrophobic bonds in amino acid residue that was also similar with the control. The interaction between the metabolite of Sargassum sp could be seen from the visualization results of LigPlot with the identical position of target protein with the control as both control and metabolite had the same amino acid residues.

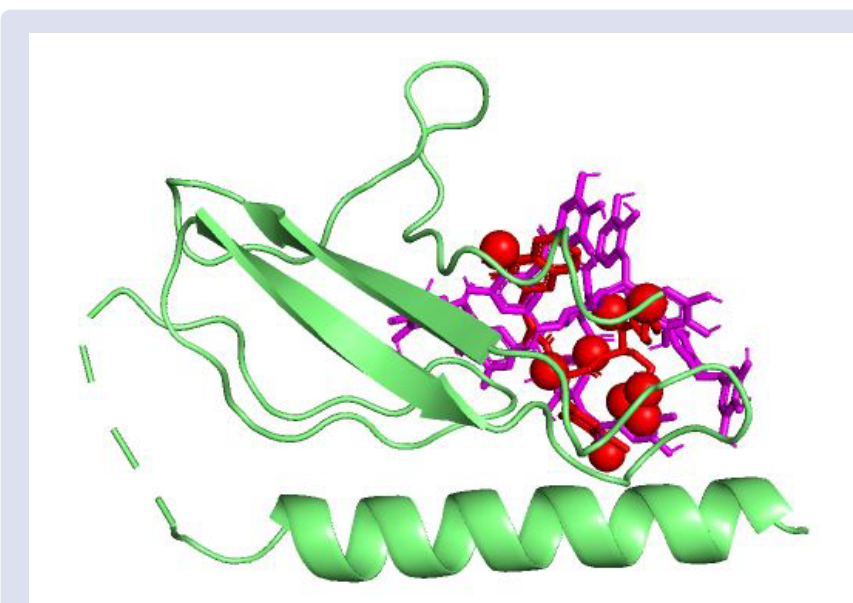

Figure 1: Visualization of CGRP docking results (color visualization in Table 3).

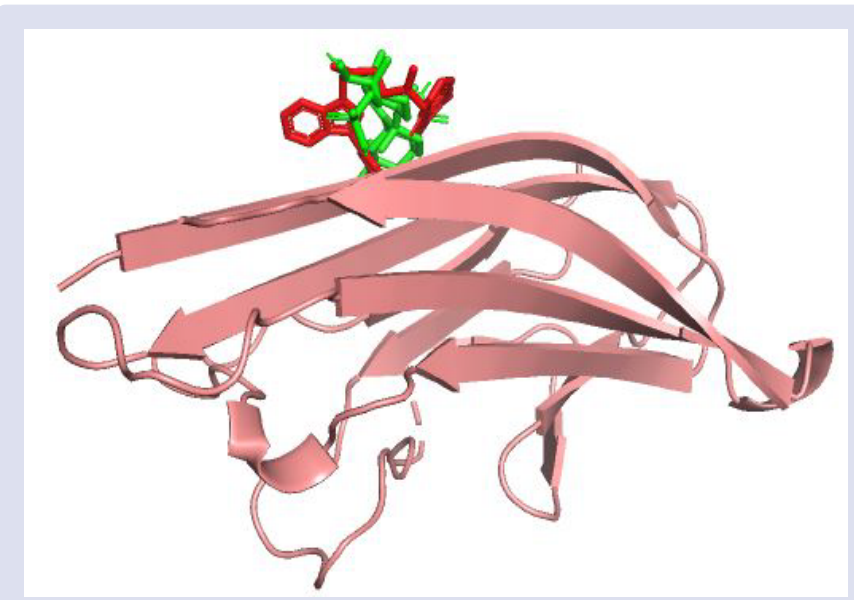

Figure 2: Visualization of TNF docking results (color visualization in table 4).

Table 3: The result of molecular docking between CGRP and ligand.

\begin{tabular}{|ccc|}
\hline Substance & $\begin{array}{c}\text { Binding Affinity } \\
\text { (kcal/mol) }\end{array}$ & Color \\
\hline Tannin & -8.1 & Violet \\
Fucoidan & -6.2 & Yellow \\
Triterpenoid & -7.1 & Green \\
Control & -7.4 & Red \\
\hline
\end{tabular}

Table 4: The result of molecular docking between TNF $a$ and ligand.

\begin{tabular}{|ccc|}
\hline Substance & $\begin{array}{c}\text { Binding Affinity } \\
\text { (kcal/mol) }\end{array}$ & Color \\
\hline Tannin & -0.8 & Violet \\
Fucoidan & -4.3 & Yellow \\
Triterpenoid & -5.7 & Green \\
Control & -6.7 & Red
\end{tabular}


Table 5: LigPlot visualization results.

\begin{tabular}{|c|c|c|c|}
\hline Receptors & Compound & Hydrophobic Bond & Hydrogen Bond \\
\hline \multirow[t]{2}{*}{ TNF- $\alpha$} & Control & $\begin{array}{l}\text { GLN61, TYR119, LEU120, LEU57, GLY121, SER60, } \\
\text { TYR59 }\end{array}$ & TYR151 \\
\hline & Triterpenoid & TYR59, LEU57, ILE118, LYS98, LEU120, TYR151 & TYR119 \\
\hline \multirow[t]{2}{*}{ CGRP } & Control & $\begin{array}{l}\text { MET42, ASP70, GLY71, ARG119, TRP124, TRP121, } \\
\text { PHE92, PHE95, ILE41 }\end{array}$ & THR122, TRP72 \\
\hline & Fucoidan & ASP70, TYR124, TRP72 & ARG119, THR122, TRP121 \\
\hline
\end{tabular}

Note: The same amino acid residue between control and seaweed metabolite ligands is displayed by the bold sign.

\section{DISCUSSION}

Based on the docking results, seaweed metabolites have great potential as inhibitors of CGRP and TNF because the binding affinity score is close to control. CGRP and TNF a increased in cephalgia conditions, it is hoped that the administration of Sargassum $s p$ can help normalize the protein levels. Similar results were found in a study by Handajani and Prabowo where brown seaweed extract (Sargassum sp) at a dose of $400 \mathrm{mg} / \mathrm{kg}$ was able to significantly reduce TNF- $\alpha$ expression and repair joint damage. The results showed that the expression of TNF- $\alpha$ in the adjuvant arthritis group with the treatment of brown seaweed extract and cold stressor decreased significantly up to $48.4 \%$ and the repair of joint damage in the metatarsophalangeal tissue was marked by the repair of chondrocyte cells. ${ }^{8}$

Tannins in the ethanol extract of Sargassum $s p$ act as free radical scavengers that can inhibit the formation of superoxide $\mathrm{O} 2$ - anions and convert them into more stable products, thereby increasing the enzyme superoxide dismutase (SOD) and reducing oxidative stress. Another study by Aulanni'am reported that Sargassum sp was able to reduce free radicals in animal models of inflammatory bowel disease.,10

Activity of anti-inflammatory and antinociceptive both in vitro and in vivo was found in Terpenoid from Cannabis. The impacts operate independently of TNF- $\alpha$. Terpenoids in Cannabis exhibit only momentary immunosuppression, thus, by using it, the acute inflammation can be overcome. Terpenoids can be abundantly found in plants as the rich source. The development of chronic joint swelling is able to be inhibited by terpenoids. Furthermore, terpenoids contribute to the various mechanisms correlated to any inflammation appearing as the reaction various etiologic factors. ${ }^{3,11}$

In addition, previous result of $\mathrm{Hu}$ C's investigation exhibited that the fall of mechanical allodynia and thermal hyperalgesia can be the result of fucoidan. The inhibition of neuroimmune activation can be impeded by fucoidan fundamentally indicated with the glial activation, cytokine production of TNF- $\alpha$, IL- $1 \beta$, IL- 6 and the activation of extracellular signal-regulated protein kinase. In previous study, any analgesic effect from intrathecal fucoidan in rats treated with spinal nerve ligation is related to the inhibition of neuroimmune activation which is also in line with the maintenance of neuropathic pain. Moreover, fucoidan's inhibition on the expression of inflammatory cytokines reciprocates to its declined hypersensitivity. ${ }^{12}$

\section{CONCLUSION}

There are three substances tannin, terpenoids and fucoidon in Sargassum $s p$, which have the potential as anti-migraine. Terpenoid and Tannin binding affinity value is higher than other substances. Terpenoids and fucoidon had similar amino acid residues. Therefore, the active substance in Sargassum sp has an inhibitory effect on the occurrence of CGRP and TNF- $\alpha$ in migraine based on in silico studies.

\section{ACKNOWLEDGMENT}

We thank the EJA Team, Indonesia (https://ejatranslation.wixsite. com/home) for editing the manuscript. This study was supported by the Medical Faculty, Hang Tuah University, Surabaya, Indonesia. The Laboratorium Biomolekuler \& Bioinformatika INBIO Indonesia for the contribution in establishing research design, acquisition of data in silico method, supplying documents/photographs interpretation of data

\section{DISCLOSURE STATEMENT}

The authors have no conflicts of interest to declare.

\section{ABBREVIATIONS}

CGRP: Calcitonin Gene-related Peptide; TNFa: Tumor Necrosis Factor $\alpha$; FAO: Food and Agriculture Organization; O2-: Superoxide; SOD: Superoxide dismutase; GLN: Glutamine; TYR: Tyrosine; LEU: Leucine; GLY: Glycine; SER: Serine; ILE: Isoleucine; LYS: Lysine; MET: Methionine; ASP: Aspartic Acid; ARG: Arginine; TRP: Tryptophan; PHE: Phenylalanine; THR: Threonin.

\section{REFERENCES}

1. Husen SA, Syadzha MF, Setyawan MF, Pudjiastuti $P$, Ansori ANM, Susilo RJK, Hayaza S, Winarni D, Darmanto W. Evaluation of the combination of Sargassum duplicatum, Sargassum ilicifolium, Abelmoschus esculentus, and Garcinia mangostana extracts for open wound healing in diabetic mice. Syst Rev Pharm. 2020; 11(9): 888-892.

2. Husen SA, Setyawan MF, Syadzha MF, Susilo RJK, Hayaza S, Ansori ANM, Alamsjah MA, IImi ZN, Wulandari PAC, Pudjiastuti P, Awang K, Winarni D. A novel therapeutic effects of Sargassum ilicifolium alginate and okra (Abelmoschus esculentus) pods extracts on open wound healing process in diabetic mice. Res J Pharm Technol. 2020; 13(6): 2764-2770.

3. Kharisma VD, Ansori ANM, Fadholly A, Sucipto TH. Molecular mechanism of caffeine-aspirin interaction in kopi balur 1 as antiinflammatory agent: A computational study. Indian J Forensic Med Toxicol. 14(4): 4040-4046.

4. Capi M, De Angelis V, De Bernardini D, De Luca O, Cipolla F, Lionetto $\mathrm{L}$, et al. CGRP receptor antagonists and 5-HT1F receptor agonist in the treatment of migraine. J Clin Med. 2021;10(7):1429.

5. Kharisma VD, Agatha A, Ansori ANM, Widyananda MH, Rizky WC, Dings TGA, Derkho M, Lykasova I, Antonius Y, Rosadi I, Zainul R. Herbal combination from Moringa oleifera Lam. and Curcuma longa L. as SARS-CoV-2 antiviral via dual inhibitor pathway: A viroinformatics approach. J Pharm Pharmacogn Res. 2022; 10(1): 138-146.

6. Moelyadi F, Utami PD, Dikman IM. Inhibitory effect of active substances of lollyfish (Holothuria atra) against the development of Plasmodium falciparum based on in silico study. Indones J Mar Sci. 2021; 26(1): 135-42.

7. Widyananda MH, Pratama SK, Samoedra RS, Sari FN, Kharisma VD, Ansori ANM, Antonius Y. Molecular docking study of sea urchin (Arbacia lixula) peptides as multi-target inhibitor for non-small cell lung cancer (NSCLC) associated proteins. J Pharm Pharmacogn Res. 2021; 9(4): 484-496

8. Handajani F, Prabowo S. The role of Sargassum duplicatum extract in reducing ankle joint edema in rats with adjuvant arthritis exposed to cold stressors. eJournal Indones Med. 2019; 7(2). 
9. Zhou C, Zhao D, Sheng Y, Tao J, Yang Y. Carotenoids in fruits of different persimmon cultivars. Molecules. 2011; 16(1): 624-36.

10. Aulanni'am, Roosdiana A, Rahmah NL. The potency of Sargassum duplicatum bory extract on inflammatory bowel disease therapy in Rattus norvegicus. J Life Sci. 2012; 6: 144-54.
11. Gallily R, Yekhtin Z, Hanuš LO. The anti-inflammatory properties of terpenoids from Cannabis. Cannabis Cannabinoid Res. 2018; 3(1): 282-90.

12. Hu C, Zhang G, Zhao Y. Fucoidan attenuates the existing allodynia and hyperalgesia in a rat model of neuropathic pain. Neurosci Lett. 2014; 571: 66-71.

\section{GRAPHICAL ABSTRACT}

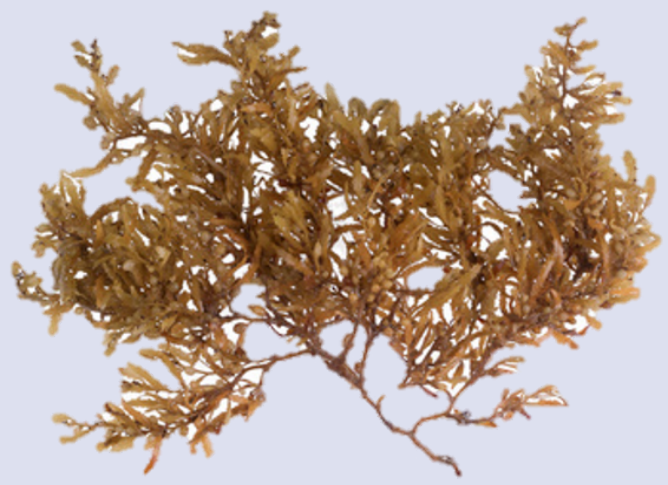

Sargassum $s p$.
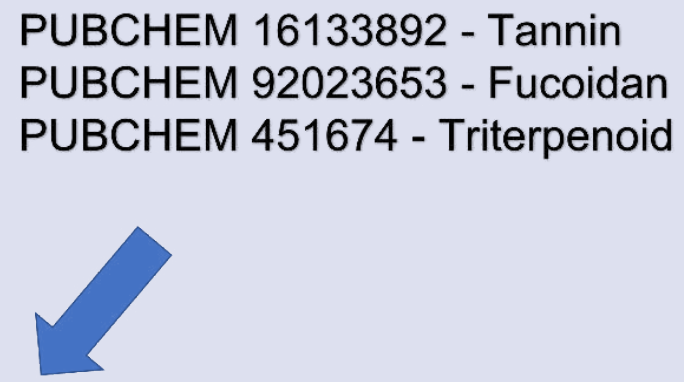

Calcitonin gene-related peptide (CGRP) Tumor necrosis factor $\alpha$ (TNF- $\alpha$ ) 


\section{ABOUT AUTHORS}

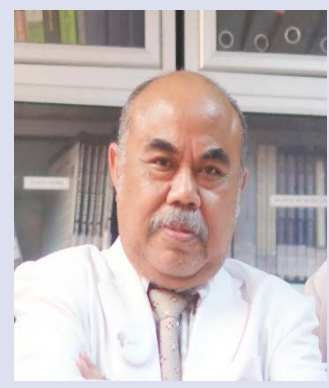

Dr. Agus Turchan, dr., SpBS(K) is a lecturer in Department of Neurosurgery Dr. Soetomo General Hospital, Faculty of Medicine Airlangga University, Surabaya.

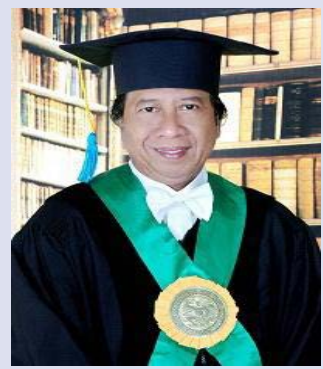

Prof. Dr. dr. Moh. Hasan Machfoed, Sp.S(K), MS is a professor in Departement of Neurology Faculty of Medicine Airlangga University, Surabaya.

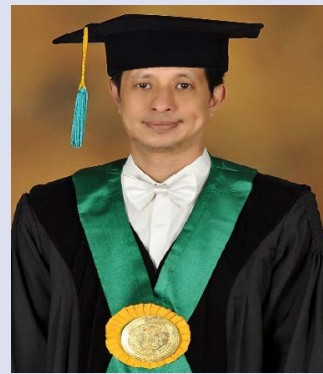

Prof. Dr. Jusak Nugraha, dr, MS., SpPK(K) is a professor in Department of Clinical Pathology, Dr.Soetomo General Hospital, Faculty of Medicine Airlangga University, Surabaya.

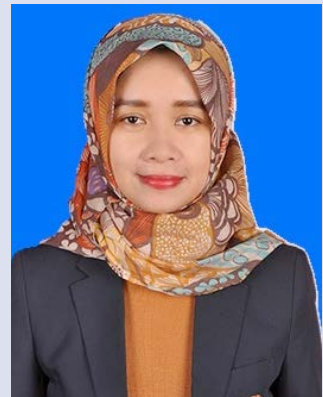

Olivia Mahardani Adam, dr., Sp.S is a lecturer in the Departement of Neurology Faculty of Medicine Hang Tuah University, Surabaya.

Cite this article: Adam OM, Nugraha J, Machfoed MH, Turchan A. In silico Study on the Promising Active Components of Terpenoid and Fucoidon from Sargassum sp. in Inhibiting CGRP and TNF- $\alpha$. Pharmacogn J. 2021;13(6)Suppl: 1715-1719. 